\title{
Les théories de la migration
}

\author{
edited by Victor Piché \\ Paris: INED 2013 \\ ISBN 978-2-73322-021-4 \\ Softcover $€ 22.00,536$ pp.
}

\author{
Reviewed by Roderic Beaujot \\ University of Western Ontario, London, Ontario
}

This is an excellent first publication in a promised series of five edited INED volumes on theory and demography. These edited volumes are designed "to support and enrich the theoretical side of demographic thinking and discussion." Each volume is to have 20 "fundamental texts" that have advanced demographic thinking, providing bases for analysis and understanding of associated phenomena. Other volumes in the series will consider fertility, nuptiality and family, mortality, and demographic regimes. The editors are asked to collect basic texts that define the common theoretical heritage of demography writ large.

Victor Piché is the ideal editor for this volume on migration, having spent a career researching migration in both South and North, and having taught a course on the topic over the years at Université de Montréal. I have never seen such a thorough introduction to an edited volume. Professor Piché builds this first chapter through an analysis that brings together sequentially the 20 chapters, following an analytic framework that both compares and gives value to the selected texts. In so doing, he refers to some 140 references, including the 20 original publications contained in the volume. No less than 11 of these references are to Pichés earlier publications, but only the introductory chapter of the present book is authored by the Editor. It is of interest that two of the articles are from the 1960s, four from the 1970s, nine from the 1980s, three from the 1990s, and the most recent two carry the date of 2000 . Also of interest is that 19 of the 20 are here translated, having been originally published in English.

The Editor makes considerable use of the two "paradigms" that he sees as dominating the post-war literature until the end of the 1980s: one based on the functionalist approach in sociology and neoliberal economics, and the other on macro-structural approaches of Marxist inspiration (p. 17). The two major sections of the book focus on the origins and causes of migration and on the effects of migration. Piché adapts an integrating conceptual framework from Goldlust and Richmond that appeared in the 1974 issue of International Migration Review 8(2) to bring together the various factors of migration and integration, at the macro and micro levels ( $\mathrm{p}$. 50). One of the important adaptations is to give more centrality to gender in thinking about migration. For an English version of Piche's integrating conceptual framework, see his chapter on immigration and integration in developed countries in Caselli et al. (2006).

The last section of the book addresses the politics of migration, particularly the rights of migrants, including the right to both emigrate and immigrate. He sees an emerging paradigm based on the globalization of migration flows, in line with more open flows of capital, goods, and services.

In the last section of the introduction, the Editor observes developments in the European Union, West Africa, and Latin America that have allowed freer movement within these areas. In my view, there could be more recognition of the importance of reasonable similarities in levels of income within these regions, and of the inter-regional economic redistributions that have made the European case viable as an open-migration area. As European states have appreciated, open migration also brings pressure to achieve similarity in social policy. 
It is interesting that the topic of migration brings authors to look at globalization so positively. The Editor's introduction is also imbued with a strong understanding of the demand for labour in developed economies. There is an appreciation that this demand is not just for high-level skills but also for care work, the secondary labour market, and underground economies. There is also a strong appreciation of cumulative causality, wherein networks, agents and intermediaries bring a continuation of migration streams once they have been established. It is also noted that these intermediaries can be facilitators, but they can also be exploitative, including trafficing and organized crime. There could be more recognition of vested interests in arguments based on skill shortages, and more discussion of conflicts between open migration and the welfare state.

\section{Reference}

Caselli, G., J. Vallin, and G. Wunsch (eds.). 2006. Demography: Analysis and Synthesis: A Treatise in Population Studies. Waltham MA: Academic Press.

Goldlust, J., and A. Richmond. 1974. A multivariate model of immigrant adaptation. International Migration Review 8(2): 193-225. 